7 (2016)

D0I: $10.18276 /$ rk.2016.7-11

Katarzyna Kucia

Uniwersytet Jagielloński

\title{
Teologia na granicy słowa, muzyki i obrazu. Przypadek opery Saint-François d'Assise Oliviera Messiaena
}

Opera, jako swoista hybryda intermedialna, jest tyleż atrakcyjnym, co problematycznym przedmiotem refleksji w dziedzinie badań muzykologiczno-literaturoznawczych. W kanonicznej dziś typologii intermedialności wypracowanej przez Wernera Wolfa jej specyfikę określa kilka rodzajów relacji intermedialnych. Po pierwsze, często bywa efektem tzw. transpozycji intermedialnej, kiedy jej korzenie fabularne, czy też tematyka sięgają konkretnych dzieł (najczęściej literackich); po drugie, nosi znamiona transmedialności, dzieląc z innymi dziedzinami sztuk pewne cechy ogólne, np. narratywność (orkiestra może pełnić rolę zewnętrznego narratora) czy motywy przewodnie; jest wreszcie - w trakcie wystawienia - egzemplifikacją plurimedialności, kombinacji i fuzji co najmniej dwóch systemów semiotycznych (Wolf, 2002: 27-28). Synchroniczne, czy raczej performatywne, współistnienie wielu mediów na scenie operowej intensyfikuje jakość przeżycia estetycznego, lecz skutecznie wymyka się językowi naukowego opisu. Zadanie staje się jeszcze trudniejsze, kiedy dzieło inkorporuje - prócz idiosynkratycznego tworzywa literacko-muzycznego - konkretne dzieła sztuk plastycznych, trawestuje zagadnienia teologiczne - implicite (w samym języku muzycznym) oraz explicite (na poziomie libretta), zawiera filozofię i elementy hinduskiej muzyki oraz czerpie w tworzywie muzycznym z ptasich śpiewów. Tak pokrótce przedstawia się Saint-François d’Assise, jeden z ostatnich utworów francuskiego kompozytora, Oliviera Messiaena. Operę tę można by nazwać dziełem totalnym w podwójnym znaczeniu: jako całości stworzonej przez jednego autora, ale także jako summę wieloletnich poszukiwań twórczych, naukowych i religijnych kompozytora. Messiaen był bowiem niezwykle wszechstronnym człowiekiem, który prócz pisania muzyki, z pasją oddawał się ornitologii, lekturze Szekspira, rozważaniom Pisma Świętego oraz myśli teologicznej. Każde spotkanie ze sztuką dźwięków francuskiego twórcy prowokuje do odtworzenia jego 
ścieżki artystycznej, której etapy - nie tyle traktowane jako „rozdziały zamknięte”, lecz raczej uzupełniające i nawarstwiające się - można by nazwać odpowiednio: via theologica, via musica oraz via melodica.

\section{Via theologica - via musica}

Nie bez kozery badacze życia i twórczości Messiaena nazywają go mistykiem i teologiem. Kompozytor już w wieku nastoletnim sięgał po teksty mistyczne, pisma ojców kościoła oraz teologów. Patronowali mu m.in. Jan Ruysbroeck, Tomasz à Kempis, Thomas Merton, św. Franciszek z Asyżu, św. Teresa z Ávila, św. Jan od Krzyża, św. Katarzyna Sieneńska oraz św. Teresa z Lisieux. Jego koncepcje teologiczne dojrzewały zaś pod wpływem katolickich myślicieli, takich jak Ernest Hello, Columba Marmion, oraz teologów: Romana Gaurdiniego oraz Hansa Ursa von Balthasara. Jednak największe oddziaływanie na jego sposób przeżywania oraz rozumienia chrześcijaństwa miał św. Tomasz z Akwinu. Opus magnum tego średniowiecznego teologa - Summa theologiae - zawsze towarzyszyło Messiaenowi jako kompozytorowi i chrześcijaninowi (Bruhn, 2008: 9).

Drugi etap drogi twórczej to próba przełożenia koncepcji teologicznych na idiom kompozytorski. W tekstach teoretycznych Messiaena znajdują się rozważania dotyczące muzycznego trwania i rytmicznych symboli wieczności, które nawiązują do koncepcji czasu św. Tomasza z Akwinu. Kompozytor rozwija naukowy i mimetyczny potencjał muzyki, czyniąc ze sztuki dźwięków narzędzie intelektualnego poznania struktury czasowej (Messiaen, 1994: 39). Równie ważną rolę w idiomie kompozytorskim odgrywają tzw. modi (Pople, 1995: 20-23). Są to układy dźwięków, zestawione według określonych relacji interwałowych. W tradycyjnym rozumieniu potraktowalibyśmy je jako skale, jednak Messiaen - w kontekście silnie odczuwanej przezeń synestezji - nazywał je po prostu kolorami (Messiaen, 1986: 52), obdarzając każdą z nich konkretną kompozycją barwną ${ }^{1}$. Jak wyznał w wywiadzie udzielonym Claude'owi Samuelowi: „Lorsque j’entends de la musique, je vois intérieurement

1 Np. mode 1. - czerwonawy fiolet (Huston Bell, 1984: 30); mode 2. - fioletowo-purpurowy; mode 3. - pomarańczowy, otoczka biała, z odrobiną opalizującej czerwieni; mode 4. - ciemnofioletowy; mode 5. - szaro-różowo-zielony, z plamkami złota w aurze mlecznej bieli, upstrzony maleńkimi plamkami czerwieni opal; mode 4. - ciemnopurpurowy; mode 5. - szaro-różowo-zielony z plamkami złota (Kaczyński, 1984: 19). 
des complexes de couleurs correspondant aux complexes de sons (...)" (Messiaen, 1986: 66) ${ }^{2}$.

Niebagatelne oddziaływanie na synestezyjnie ujmowaną melodykę miała twórczość Roberta Delaunay (Messiaen, 1986: 46)³. Na jego obrazach kompozytor odnalazł barwy, jakie objawiały mu się w czasie słuchania muzyki. Szczególnie cenił jego technikę zestawiania barw dopełniających, tj. takich par kolorów, które połączone ze sobą tworzą biel, czerń lub szarość, np. czerwony i zielony, fioletowy i żółty, niebieski i pomarańczowy. Najbardziej fascynujące jest to, że oko ludzkie, patrząc na dany kolor, jest w stanie wychwycić jego uzupełniający odpowiednik. Wystarczy popatrzeć przez dłuższą chwilę na czerwony prostokąt na białym tle, potem przenieść wzrok na białą przestrzeń, by zobaczyć jaśniejącą zieleń (Messiaen, 1986: 46, 66).

Za pomocą modi Messiaen stara się odtworzyć ten efekt w muzyce. Dźwiękowym odpowiednikiem barwy dopełniającej są dla niego alikwoty. By przenieść to wizualne wrażenie na grunt audialny, wyzyskiwał możliwości rezonansu: dobarwiał swoje akordy sekstą, trytonem, który jest 11. alikwotem, a także tworzył współbrzmienia o skoncentrowanym rezonansie nadrzędnym i podrzędnym, które stanowią tło dla głosu wokalnego i wzmacniają jego składniki alikwotowe (Huston Bell, 1984: 26). Wydaje się, że ten zabieg kompozytorski miał swoje źródła w Messiaenowskim pragnieniu odkrywania śladów Bożej obecności w świecie natury ${ }^{4}$. To, co widzialne skrywało dla niego to, co niewidzialne. Pogłos, czy też rezonans był właśnie takim efemerycznym rodzajem śladu. Pasja poszukiwania tego, co mogło mieć choćby najsłabiej widoczny polor rzeczywistości nadprzyrodzonej wyraża się nie tylko w muzyce, ale także w prywatnym życiu kompozytora. Od dzieciństwa interesował się Szekspirowskimi postaciami ze świata fantastycznego, czytał książki science-fiction, śledząc równocześnie dokonania kosmologów (Messiaen, 1986: 15). Jednak jedynie prawdziwy świat nadprzyrodzony odnalazł, jak pisał z godną podzi-

2 „Gdy słyszę muzykę, widzę w moim umyśle kompleksy kolorów, odpowiadające kompleksom dźwięków (...)”. Cytaty przytoczone w artykule podane są w przekładzie autorki, chyba że w przypisie zaznaczono inaczej.

3 Ulubieni artyści Messiaena to również: Matthias Grünewald (Messiaen, 1986: 46), Charles Blanc-Gatti, Mikalojus Konstantinas Čiurlionis, Jean Lurçat, Odilon Redon oraz Marc Chagall (Kaczyński, 1984: 28).

4 Kompozytor $\mathrm{z}$ odwagą wyznał: „Nie wierzę w tonalność, nie wierzę w modi, nie wierzę w serię... Myślę, że są to wszystko złudy. Dla mnie jedyną rzeczą prawdziwą w muzyce jest rezonans naturalny. I dlatego wierzę w barwę, bo barwa - podobnie jak muzyka - jest wibracją naturalną. Reszta to wymysły ludzi, którzy usiłują z tego zrobić słowniki, ślicznie ilustrowane tablicami synoptycznymi” (Kaczyński, 1984: 211). Cytat podaję w tłumaczeniu Tadeusza Kaczyńskiego. 
wu otwartością i prostotą, w wierze katolickiej, której wspaniałość chciał wyrażać poprzez niezwykle „nasycony” - oddziaływaniem różnych dziedzin artystycznych i naukowych - język muzyczny (wcielenie Tomaszowej maksymy fides et ratio), który podsumował w następujący sposób ${ }^{5}$.

La première idée que j'ai voulu exprimer, celle qui est la plus importante parce qu'elle est placée au-dessus de tout, c'est l'existence des vérités de la foi catholique. ( ... ) je suis né croyant et il se trouve que les textes sacrés m’ont frappé dés mon enfance. Un certain nombre de mes œuvres sont donc destinées à mettre en lumière les vérités théologiques de la foi catholique. C'est la le premier aspect de mon œuvre, le plus noble, sans doute le plus utile, le plus valable, le seul peut-être que je ne regretterai pas à l'heure de ma mort. ( ... ) Je pense que la nature nous surpasse infiniment et je lui ai toujours demandé des leçons; par goût, j’ai aimé les oiseaux, j’ai donc spécialement interrogé les chants des oiseaux : j'ai fait de l'ornithologie. Il y a dans ma musique cette juxtaposition de la foi catholique, du mythe de Tristan et Yseult, et l'utilisation excessivement poussée des chants d'oiseaux. Mais il y a aussi l'emploi de la métrique grecque, des rythmes provinciaux de l'Inde antique ou "deçi-tâlas ", plusieurs procédés rythmiques personnels tels que les personnages rythmiques ${ }^{6}$, les rythmes non rétrogradantes, les permutations symétriques. Enfin, il y a ma recherche du son-couleur, qui est la plus grande caractéristique de mon langage.

(Messiaen, 1986: 21)

5 Messiaen zapytany o XIX-wieczną opozycję nauki i religii odpowiedział: „Dieu nous a donné un cerveau pour que nous nous en servions, pour que nous affinions nos connaissances, pour que nous approfondissions notre réflexion, mais, tant que nous vivrons sur terre, nous ne posséderons jamais les outils de la connaissance parfaite” [„Bóg dał nam mózg, żebyśmy mogli poszerzać naszą wiedzę, wyostrzyć myśl, ale dopóki żyjemy na ziemi, dopóty nie posiądziemy narzędzi doskonałego poznania”] (Messiaen, 1986: 18).

6 Messiaen wyjaśnia „postaci rytmiczne” przy okazji Święta wiosny Igora Strawińskiego, w którym to dziele dostrzega trzy rodzaje symultanicznie występujących rytmów: atakujący, atakowany i nieruchomy (Messiaen, 1960: 4).

7 „Pierwszą ideą, którą chciałem wyrazić, najważniejszą, ponieważ jest ponad wszystkim, jest istnienie prawd wiary katolickiej. (...) urodziłem się jako wierzący i Pismo Święte zafascynowało mnie już w dzieciństwie. Pewna liczba moich utworów jest przeznaczona do tego, by naświetlać prawdy teologiczne wiary katolickiej. To pierwszy aspekt mojego dzieła, najszlachetniejszy i bez wątpienia najbardziej przydatny, najwartościowszy, i być może jedyny, którego nie będę żałować w godzinie mojej śmierci. (...) Myślę, że natura przewyższa nas nieskończenie i że zawsze się od niej uczyłem; z upodobaniem, kochałem ptaki, badałem ptasi śpiew: uprawiałem ornitologię. W mojej muzyce odnaleźć można reprezentacje wiary katolickiej, mitu Tristana i Izoldy i szerokie wykorzystanie śpiewu ptaków. Ale są w niej także metryka grecka, rytmy z różnych regionów starożytnych Indii lub «deçi-tâlas», co więcej, postaci rytmiczne, rytmy nieodwracalne i permutacje 


\section{Via melodica - éblouissement}

Ostatni etap drogi - via melodica - to przełożenie zdobytych rozwiązań twórczych na grunt muzyki wokalnej, w której czynnik melodyczny - obok rytmiki najbardziej ceniony przez kompozytora element dzieła muzycznego (Maas, 2009: 68) - stanowi główny komponent formotwórczy i, najczęściej, jest powierzony głosowi ludzkiemu. W melodyce dostrzegał Messiaen przede wszystkim pierwiastek kolorystyczny, ale także, podobnie jak Balthasar, uważał ją za najbardziej tajemniczą właściwość muzyki (Maas, 2009: 112). Messiaen skomponował liczne cykle wokalno-instrumentalne - Poèmes pour Mi, Cinq Rechants, Harawi, Chants de terre et de ciel, by wymienić najbardziej znane. Jednak przez wiele lat opierał się pomysłowi napisania opery. Uczynił to dopiero u schyłku swojej twórczości, w latach 1975-1983, kiedy to za namową dyrektora opery paryskiej zdecydował się stworzyć dzieło sceniczne (Bruhn, 2008: 149-150).

Głównym protagonistą utworu jest św. Franciszek z Asyżu, patron muzyków i poetów, miłośnik przyrody, śpiewu ptaków; człowiek, który - zdaniem kompozytora - był najbardziej podobny do Chrystusa. Libretto powstało w oparciu o kilka źródeł, głównie były to anonimowe Kwiatki św. Franciszka, rozważanie O przenajświętszych stygmatach św. Franciszka oraz oryginalne pisma Biedaczyny: Pieśń stoneczna, Testament, jak również zachowane modlitwy. Ważną rolę w tworzeniu libretta miały również cytaty z Pisma Świętego oraz Summy Teologicznej św. Tomasza z Akwinu, a także fragmenty poezji Johna Keatsa. W mniejszym stopniu Messiaen korzystał z informacji zawartych w Vita prima $i$ Vita secunda Tomasza z Celano oraz z kronik Legenda major i Legenda minor św. Bonawentury (Dingle, 2007: 302-304). Z kolei scenografia w dużej mierze była inspirowana konkretnymi przedstawieniami malarskimi. Wygląd św. Franciszka wzorowany był na fresku autorstwa Cimabue Madonna ukoronowana między Aniotami i św. Franciszkiem, z ok. 1280 roku, znajdującego się w Bazylice św. Franciszka w Asyżu. Natomiast pierwowzorem gestów i sposobu poruszania się głównego bohatera było przedstawienie Giotta z fresku powstałego 20 lat później, ok. 1300 roku, zatytułowanego Święty Franciszek gtosi kazanie do ptaków. Dla stworzenia wizerunku trędowatego inspiracją była postać z obrazu Matthiasa Grünewalda Kuszenie Świętego Antoniego z ołtarza w Isenheim. Jednak najistotniejsze znaczenie dla kompozytora miał wygląd Anioła. Jego postać miała być odzwierciedleniem Archanioła Gabriela z obrazu

symetryczne. Wreszcie, moje poszukiwania na polu dźwięk-kolor, które są najbardziej charakterystyczne dla mojego języka”. 
Zwiastowanie Fra Angelico, z ok. 1451 roku, zachowanym w Museo di San Marco we Florencji. To, co szczególnie zafrapowało kompozytora, to dość oryginalny jak na tamtą epokę - sposób przedstawienia skrzydeł boskiego posłańca. Malarz umieścił na nich równoległe, kolorowe pasma (Dingle, 2007: 310).

Operę tworzą trzy akty, podzielone na osiem obrazów, odpowiednio zatytułowanych: La Croix, Les Laudes, Le baiser au Lépreux, L'Ange voyageur, L'Ange musicien, Le prêche aux oiseaux, Les stigmates oraz La mort et la Nouvelle Vie (Messiaen, 1988-1992). Dzieło pokazuje duchową ścieżkę świętego - imitatio Christii jego stopniową transfigurację. Punktami węzłowymi na tej drodze są momenty, w których Bóg, na prośbę świętego Franciszka, interweniuje. Po raz pierwszy ma to miejsce podczas spotkania św. Franciszka z Trędowatym. Asyżanin modli się żarliwie o miłość do bliźniego. Jego modlitwa zostaje wysłuchana, Franciszek pokonuje strach i obrzydzenie wobec Trędowatego i składa na jego twarzy pocałunek, uzdrawiając go. Na początku III aktu Franciszek prosi Boga o możliwość współcierpienia z Chrystusem ukrzyżowanym i niebawem zostaje wysłuchany, otrzymując na górze Alwernia stygmaty. W II akcie, w V obrazie opery, wyraża pragnienie zakosztowania w uczcie niebieskiej. Bóg spełnia i tę prośbę, jednak w sposób nieoczekiwany. Ten moment wydaje się być centralnym punktem opery i można zaryzykować twierdzenie, że jest to także kulminacja znaczenia twórczości wokalnej francuskiego kompozytora w ogóle.

Część ta zaczyna się śpiewem sparafrazowanego fragmentu „Pieśni słonecznej” św. Franciszka:

Loué sois-tu, mon Seigneur, pour frère Soleil, qui donne le jour, et par qui tu nous éclaires. Il est beau, rayonnant, avec grande splendeur: de Toi, Très-Haut, il est le symbole. Loué sois-tu, mon Seigneur, pour sœur Lune, et pour les étoiles: dans le ciel tu les a créées, claires, précieuses et belles. Loué sois-tu, Seigneur !«Autre est l'éclat du soleil, autre l'éclat de la lune, autre l'éclat des étoiles. Et même une étoile diffère en éclat d'une autre étoile. Ainsi en va-t-il de la résurrection des morts».

(Messiaen, 1992-2004: 31) ${ }^{8}$

\footnotetext{
8 „Pochwalony bądź, mój Panie, przez brata Słońce, który daje nam dzień i przez który nas oświetlasz. Jest piękny, promienny, bardzo zjawiskowy: Ciebie, Najwyższego, jest obrazem. Pochwalony bądź, mój Panie, przez siostrę Księżyc i przez gwiazdy: na niebie je stworzyłeś, jasne, bezcenne i piękne. Pochwalony bądź, Panie! «Inny jest blask słońca, inny blask księżyca, inny blask gwiazd. I jedna gwiazda różni się od innej gwiazdy. Tak samo będzie ze zmartwychpowstaniem zmarłych»".
} 
Następnie Asyżanin modli się do Boga tymi słowami’:

O Dieu éternel, Père Tout-Puissant, donne-moi de goûter un peu de cet ineffable festin, où avec ton Fils et le Saint Esprit, tu es pour te Saints la lumière, la lumière véritable, le comble des délices, et la félicité parfaite!

(Messiaen, 1992-2004: 31) ${ }^{10}$

We wszystkich zacytowanych fragmentach pojawia się motyw światła. Początkowo w odniesieniu do materialnych bytów, których blask jest cechą konstytutywną, jak słońce i gwiazdy, lub odbijających światło, jak księżyc, ale także i przede wszystkim w stosunku do Boga. Znów elementy świata empirycznego rzucają „światło” na to, co poza nim. Messiaen, podobnie jak św. Tomasz, interesował się analogią, w rozumieniu założonego podobieństwa między Stwórcą a stworzeniem, ale także przypadkami nadprzyrodzonego sposobu objawiania człowiekowi woli Boga. Stąd szczególnym zainteresowaniem darzył kompozytor Aniołów, studiując pisma Akwinaty poświęcone naturze i postaciom anielskim. W cyklu organowym Méditations sur le Mystère de la Sainte Trinité opracował tzw. langage communicable, który jest symbolem mowy anielskiej. Poszczególnym wysokościom i ich długościom trwania przypisane są litery alfabetu. W ten sposób Messiaen przełożył na muzykę fragmenty Summy teologicznej Akwinaty (Shenton, 1998: 225). Wątek mowy aniołów pojawia się również w wypowiedzi św. Franciszka w części Kazanie do ptaków, w której Asyżanin zwraca uwagę swoim skrzydlatym braciom, by wyrażali wdzięczność Bogu za to, że: „Il vous a permis de chanter si merveilleusement, que vous parlez sans mots, comme la locution des Anges, par la seule musique" (Messiaen, 1992-2004: 37-38) ${ }^{11}$. Messiaen zatem podniósł sztukę dźwięków do

9 Stefan Keym w swoim studium poświęconym operze Messiaena wskazuje pierwowzór tej modlitwy. Jest ona parafrazą modlitwy dziękczynnej po komunii św., prawdopodobnie autorstwa św. Tomasza z Akwinu (Keym: 82). „Dzięki Ci czynię Panie Święty, Ojcze Wszechmogący, Wieczny Boże (...). I proszę Cię, abyś mnie grzesznika doprowadzić raczył do onej niewymownej uczty, na której z Synem Swoim i Duchem Świętym jesteś dla wybrańców swych prawdziwą Światłością, zupełnym nasyceniem, weselem wiekuistym, pełnią rozkoszy i szczęściem doskonałym. Amen”. Tekst modlitwy podaję w tłumaczeniu ze strony internetowej: http://www.duchprawdy.com/ ofiara_mszy_sw_rozwazania_i_modlitwy.htm [dostęp: 30.03.2015].

10 „O wieczny Boże, wszechmogący Ojcze, daj mi zakosztować tej niewysłowionej uczty, podczas której, z Twoim Synem i Duchem Świętym, jesteś dla swoich świętych prawdziwym światłem [podkr. - K.K.], koroną zachwytów i doskonałym szczęściem!"

11 „On pozwolił im śpiewać tak cudownie, że mogą mówić bez słów, tak jak aniołowie, którzy wyrażają się tylko muzyką". 
języka niebiańskiego. Muzyka staje się pasem transmisyjnym, przez który ludzkość może kontaktować się ze światem nadprzyrodzonym.

\section{Éblouissement}

Zstąpienie Anioła jest wydarzeniem centralnym w V obrazie opery. Jest ono odpowiedzią Boga na prośbę św. Franciszka, a jego przyjście jest zapowiedziane przez śpiew pustułki zwyczajnej (Gheppio), z którą Święty rozmawia na początku sceny. Następuje potem bardzo intensywne pod względem harmonicznym, instrumentacyjnym i dynamicznym intermezzo. Pojawia się Anioł uniesiony w tańcu tuż nad ziemią i przywołuje Franciszka, by oznajmić mu, że spełnienie jego prośby, tj. zakosztowania w niewysłowionym szczęściu niebieskim, niesie ze sobą pewne ryzyko, bowiem umysł ludzki nie jest w stanie pojąć splendoru Boskiej Prawdy.

\section{L'Ange}

Ah! Dieu nous éblouit [podkr. - K.K.] par excès de

Vérité.

La musique nous porte à Dieu par

défaut de Vérité.

Tu parles à Dieu en musique: il va te répondre en musique. Connais la joie des bienheureux par suavité de couleur et de melodie.

Et que s'ouvrent pour toi les secrets, les secrets de la Gloire!

Entends cette musique qui suspend la vie aux échelles du ciel, entends la musique de l'invisible...

12 „Anioł: Ach! Bóg olśniewa [oślepia - K.K.] nas nadmiarem Prawdy. Muzyka prowadzi nas do Boga przez brak Prawdy. Mówisz do Boga muzyką: on odpowie ci muzyką. Poznaj radość błogosławionych poprzez słodycz kolorów i melodii.

I niech otworzą się dla Ciebie tajemnice, tajemnice Chwały!

Usłysz muzykę, która zawiesza życie na drabinie nieba, usłysz muzykę niewidzialnego..." 
Wypowiedź Anioła jest nawiązaniem do kilku fragmentów z pism św. Tomasza z Akwinu. Wątek oślepienia znajduje się w pierwszej części Summy teologicznej, w której Akwinata porównuje człowieka, spoglądającego na Stwórcę, do nietoperza oślepionego przez słońce ${ }^{13}$. Z kolei zdanie „muzyka prowadzi nas do Boga poprzez brak Prawdy” zostało zainspirowane jednym z passusów z drugiej części Summy teologicznej, w której św. Tomasz rozważa, jak funkcjonuje ludzka wyobraźnia oraz sensy figuratywne.

Natomiast w stanie obecnego życia nie możemy oglądać samej w sobie prawdy Bożej. Jak uczy Dionizy, promień Bożej prawdy musi nam zajaśnieć pod jakimiś postrzegalnymi symbolami: różnie jednak, zależnie od różnego stanu poznania ludzkiego. (...)

Jak rozum ludzki nie pojmuje obrazowania stosowanego w poezji, ponieważ nie wszystko w nim jest prawdą, tak również rozum ten nie może doskonale pojmować tajemnic Bożych, ponieważ ich prawda przekracza jego siły.

(Św. Tomasz z Akwinu, 1985: 170-171)

Słuszność metafory i porównania zasadza się na analogii oraz proporcjonalności przedmiotów materialnych do ludzkich możliwości poznawczych. Inne sposoby przekazywania Boskich komunikatów, jak pisze św. Tomasz, mogą okazać się niebezpieczne dla człowieka.

Inspiracją do umieszczenia tego wątku z Summy teologicznej w operze stała się publikacja Lire François d'Assise autorstwa Louisa Antoine'a. Autor interpretuje przytoczony fragment Summy jako założenie o tym, że to, co boskie, lepiej wyraża się poprzez symbole, obrazy czy nawet urojenia, niż poprzez abstrakcyjne idee. Stąd, jak pisze Antoine, w Biblii odnaleźć można wszystkie rodzaje literackie, a nawet muzykę, która wraz z poezją „wyśpiewuje chwałę Boga” (Antoine: 73). Podobny pogląd wyraził również Messiaen, podkreślając w szczególności niezwykłe możliwości reprezentacyjne sztuki dźwięków:

Les arts, et spécialement la musique, mais aussi la littérature et la peinture, nous permettent de pénétrer dans des domaines qui sont non pas irréels, mais au-delà

\footnotetext{
13 Św. Tomasz pisał: „Odpowiadam, że wszystko jest poznawalne w takim stopniu, w jakim jest urzeczywistnione. Bóg, który jest czystym urzeczywistnieniem wolnym od wszelkiej przymieszki możności, jest sam w sobie w najwyższym stopniu poznawalny. To jednakże, co w sobie jest w najwyższym stopniu poznawalne, nie jest poznawalne dla dowolnego intelektu, jeśli przedmiot poznania wykracza poza intelekt. Podobnie nietoperz nie jest zdolny do widzenia słońca, które jest najlepiej widoczne, ze względu na nadmiar światła. Na tej podstawie niektórzy twierdzą, że żaden intelekt stworzony nie może widzieć istoty Boga” (Św. Tomasz z Akwinu, 1999: 138).
} 
de la réalité. [...] Or je pense que la musique, plus encore que la littérature et la peinture, est capable d'exprimer cet aspect du rêve, des contes de fées, de l'au-delà, cet aspect «surréel» des vérités de la foi. C'est en ce sens que la musique exprime tout cela par défaut de vérité, parce qu’elle n’est pas dans la réalité vraie. Dieu seul est l'unique réalité vraie, tellement vraie qu'elle dépasse toute vérité.

(Messiaen, 1986: 256) ${ }^{14}$

W operze Bóg pozwala uczestniczyć św. Franciszkowi w niebiańskiej uczcie właśnie za sprawą muzyki Anioła, grającego na wioli. Element fantastyki i wrażenie nadnaturalnego brzmienia potęgują fale Martenota. Święty Franciszek, niezdolny do przyjęcia „nadmiaru Prawdy”, która dociera do niego poprzez dźwięki anielskiej wioli, traci przytomność. To efekt tzw. éblouissement-stanu olśnienia i wyrwania z rzeczywistości. Jak pisze Sander van Maas, „dosłownie odnosi się ono do «oślepienia» wewnętrznych zmysłów na skutek spotkania z Bogiem”. Éblouissement to jedno z pojęć, którym kompozytor posługiwał się, by określić stan jednocześnie religijnego i estetycznego zachwytu (Maas, 2007: 79). Przy okazji autorskiego komentarza do Couleurs de la cité céleste, pisał o tym, że dźwięki-kolory (synestezyjne modi) symbolizują Państwo Boże i Tego, który je zamieszkuje, „poza czasem, poza przestrzenią”. Wspomniany utwór, zainspirowany Apokalipsą, miał reprezentować éblouissement wywołane przez wielość tytułowych Barw Niebios (Messiaen, 1963: 3). Messiaen odniósł się do tego doznania również w partyturze do Et exspecto resurrectionem mortuorum i w nutach do Méditations sur le Mystère de la Sainte Trinité, a także w Quatuor pour la fin du temps (Maas, 2007: 80). Genezą tego doświadczenia było zetknięcie się młodego kompozytora ze sztuką witrażową w średniowiecznych świątyniach. Widok oszałamiającej ferii kolorów zrobił na nim tak głębokie wrażenie, że do końca życia starał się je odtwarzać w swojej muzyce. „When one sees a stainedglass window, one does not immediately see all the figures. One has a sensation of colour, and one is dazzled. One has to shut one's eyes" (Benson) ${ }^{15}$. Doznanie

\footnotetext{
14 „Sztuka, a przede wszystkim muzyka, ale także literatura i malarstwo, pozwalają nam zgłębiać dziedziny, które nie są nierealne, ale [które znajdują się] ponad rzeczywistością. (...) Teraz myślę, że muzyka, nawet bardziej niż literatura czy malarstwo, jest zdolna do wyrażenia tego, co senne, baśniowe, a także tego nadzwyczajnego aspektu prawd wiary. W tym sensie muzyka wyraża wszystko poprzez brak prawdy, ponieważ nie odnosi się do zewnętrznej [realnej] rzeczywistości. Bóg sam jest jedyną prawdziwą rzeczywistością, tak prawdziwą, że przewyższa całą prawdę”.

15 „Gdy ktoś patrzy na witraże, nie widzi jednocześnie wszystkich przedstawionych w nim postaci. Doznaje koloru, i jest nim oszołomiony, porażony. Musi zamknąć oczy”. W swoim wykładzie z 1977 w Notre-Dame Messiaen opisał to doznanie jeszcze bardziej szczegółowo: "What happens in the stained-glass windows of Bourges, in the great windows of Chartres, in the rose-windows
} 
to nie tylko chciał oddać w muzyce, ale także wywołać je za sprawą synestezyjnie percypowanej muzyki. Pragnąt, by słuchacz niewtajemniczony w meandry techniki kompozytorskiej mógł współdzielić chociaż część tego doświadczenia z twórcą, który opisywał je następująco:

(...) lorsque j'entends, ou lorsque je lis une partition en l'entendant intérieurement, je vois intellectuellement des couleurs correspondantes qui tournent, bougent, se mélangent, comme les sons tournent, bougent, se mélangent, et en même temps...

(Messiaen, 1986: 39) $)^{16}$

Éblouissement, pierwotnie wywołane przez migotliwe i stapiające się barwy witraży, u Messiaena ewokowane jest przez muzykę, dynamicznie zmieniającą swoje kolory. W ten sposób wspomniane doświadczenie zyskuje wymiar par excellence synestezyjny. Kompozytor nie zatrzymał się jednak na postrzeganiu tego zjawiska jako wrażenia wyłącznie estetycznego, lecz upatrywał w nim cech religijnych. Według Messiaena miał to być element mistagogii, a więc wprowadzenia do doświadczenia mistycznego, przemieniającego wnętrze człowieka. Traktował go jako docelowe doznanie, jakie ma wywołać jego muzyczno-religijna estetyka, czyniąca w ten sposób z muzyki przedsmak raju:

Coloured music does that which the stained-glass windows and rose-windows of the Middle Ages did: they give us dazzlement (éblouissement). Touching at once

of Notre-Dame in Paris and in the marvellous, incomparable glasswork of the Sainte-Chapelle? First of all there is a crowd of characters, great and small, which tell us of the life of Christ, of the Holy Virgin, of the Prophets, and of the Saints: it is a short of catechism by image. This catechism is enclosed in circles, medallions, trefoils, it obeys the symbolism of colours, it opposes, it superimposes, it decorates, it instructs, with a thousand intentions and a thousand details. Now, from a distance, without binoculars, without ladders, without any object to come to the aid of our failing eye, we see nothing; nothing but stained-glass window all blue, all green, all violet. We do not comprehend, we are dazzled!” (Messiaen, 2001: 13). (Co się dzieje w witrażach w Bourges, w olbrzymich oknach Chartres, w rozetach Notre-Dame w Paryżu i we wspaniałych, nieporównywalnych szklanych arcydziełach Sainte-Chapelle? Po pierwsze jest tam mnóstwo postaci, dużych i małych, które opowiadają nam o życiu Chrystusa, Świętej Dziewicy, Proroków i Świętych: to rodzaj katechizmu w obrazie. Ten katechizm jest zamknięty w kołach, medalionach, trójliściach (treflach), wyrażony zostaje w symbolice koloru, przeciwstawia się sobie, nawarstwia, dekoruje, dopasowuje się z tysiącem znaczeń i tysiącem szczegółów. Teraz, z dystansu, bez okularów, bez drabin, bez żadnych przedmiotów wspierających nasze zawodne spojrzenie, nie widzimy nic; nic, prócz witraży całych w błękicie, zieleni i fiolecie. Nie rozumiemy, lecz jesteśmy oszołomieni!”).

16 „...) kiedy słyszę muzykę lub czytam partyturę w myślach, wizualizuję odpowiadające [dźwiękom] kolory, które obracają się, zmieniają, łączą ze sobą, tak jak dźwięki obracają się, zmieniają, łączą jednocześnie...” 
our noblest senses: hearing and vision, it shakes our sensibilities into motion, pushes us to go beyond concepts, to approach that which is higher than reason and intuition, that is, FAITH.

(Messiaen, 2001: 15) $)^{17}$

Messiaen głęboko wierzył i otwarcie manifestował swoje przekonanie o tym, że człowiek po zmartwychwstaniu, w nowym, przemienionym ciele będzie w pełni i nieustannie doświadczał éblouissement. Muzyka na ziemi ma stać się wehikułem, dzięki któremu już w stanie obecnym człowiek może doznawać częściowej radości życia w przyszłym świecie. W podsumowaniu swojego wystąpienia w Notre-Dame Messiaen wyjaśnił, dlaczego tak wielką wagę przykładał do relacji dźwięk-kolor i samego éblouissement. Pragnął, by jego twórczość stała się choć na moment przejściem ku temu, co jest poza, ku niewidzialnemu i niewyrażalnemu, które może być uobecnione poprzez dźwięk-kolor, i jest zwieńczone odczuciem éblouissement (Maas, 2007: 82).

Można zaryzykować twierdzenie, że taka muzyka staje się ikoną w znaczeniu umożliwienia uczestniczenia w tym, co ponadzmysłowe, jak sugeruje w swoim studium o éblouissement Sander van Maas (2007: 94). Wątek funkcjonowania ikony w opozycji do idola we współczesnej myśli filozoficznej rozwinął Jean-Luc Marion. Idol, jako przeciwieństwo ikony, jest przedstawieniem Boga, które jest w pełni dziełem człowieka. Nie ma w nim nic, co by nie pochodziło z ludzkiego wyobrażenia na temat Stwórcy. Spojrzenie na idola jest więc spojrzeniem samozwrotnym, bowiem odbite spojrzenie nie wnosi niczego nowego. Ikona z kolei pochłania ludzkie spojrzenie i unosi je dalej. Staje się wezwaniem i jednocześnie etycznym wyzwaniem dla człowieka. Ikonę można porównać z twarzą drugiego człowieka - nie odbieramy jej tylko wizualnie, lecz nadstawiamy także uszu, by przemówiła. Aspekt widzialności staje się mniej ważny, ponieważ ikona zaprasza do tego, co niewidzialne (Zawadzki, 2014: 136-153). Stąd muzyka Messiaena - „kolorowa” w sensie zmysłów wewnętrznych, lecz empirycznie niewidzialna - ma szansę stać się muzycznym ekwiwalentem ikony. Na korzyść tego założenia przemawia również pewna skromność kompozytora, który inspiracji szukał przede wszystkim w naturze i prawach akustyki. Jednak rozstrzygnięcie kwestii, na ile opera byłaby dziełem o walorach ikony, wymagałoby odrębnego studium.

17 „Pełna barw muzyka działa tak samo, jak witraże i rozety w Średniowieczu: są źródłem olśnienia, porażenia, oszołomienia. Dotykając w jednym momencie naszych najszlachetniejszych zmysłów: słyszenia i widzenia, wprowadza naszą wrażliwość w ruch, pcha nas do wyjścia poza koncepty, do zbliżenia się do tego, co jest wyżej niż rozum i intuicja, tj. do WIARY”. 
W ostatniej scenie utworu konający Franciszek wspomina spotkanie z Aniołem -Muzykiem. Wspomnienie to staje się natchnieniem do modlitwy: „Panie, oświeć mnie Twoją Obecnością! Uwolnij mnie, odurz mnie, oślep mnie Twoim nadmiarem Prawdy!”. Po tych słowach, według instrukcji zapisanej w partyturze, miejsce spoczynku Świętego zalewa skoncentrowany słup oślepiającego światła. Śpiew i gra Anioła stają się dla św. Franciszka przejściem - passaggio - prowadzącym od muzyki do mistyki, a moment śmierci jest ostatnim stopniem zjednoczenia z Bogiem. Nie bez powodu zatem Messiaen w końcowej scenie wprowadza reminiscencję $\mathrm{V}-$ mistagogicznego obrazu opery.

\section{Kolor i obraz w dźwięku}

Należałoby rozważyć kwestię, jakimi konkretnie środkami - prócz nadania modi własności kolorystycznych - Messiaen przekłada éblouissement na muzykę. Pomimo tego, że kompozytor nie wyjaśnił wprost, w jaki sposób chciałby osiągnąć ten efekt, możemy na podstawie wcześniej cytowanych wypowiedzi wymienić kilka cech idiomu stylistycznego, które mogłyby się łączyć z tym wrażeniem. Jedną z nich jest operowanie rejestrami. Pojawienie się Anioła jest zapowiedziane szybkimi glissandami w górę w smyczkach i w partii fal Martenota (od numeru 60.) (Messiaen, 1988-1992). Zwiastunem wkroczenia sacrum do profanum są również permutacje symetryczne, jako odzwierciedlenie naruszenia kierunkowości czasu, powierzone fletowi piccolo i pozostałej grupie fletowej (numery 55., 57., 59.) (Messiaen, 1988-1992) ${ }^{18}$. Wykonywane jakby beznamiętnie - jak zauważa Siglind Bruhn - są symbolem całkowitej odmienności Anioła (Bruhn, 2008: 188). Kolejną cechą - dostrzegalną już po pierwszym przesłuchaniu - jest specyficzny dobór instrumentarium. W momencie poprzedzającym śpiew Anioła-Muzyka instrumentacja wyraźnie gęstnieje, zwiastując nadejście sacrum. Muzyczna zapowiedź jest tak potężna w brzmieniu, że można by ją uznać za symbol mysterium tremendum z koncepcji religiologicznej Rudolfa Otto (takty 64.-66.) (Messiaen, 1988-1992;

\footnotetext{
18 Permutacje symetryczne to autorski wynalazek Messiaena - swoiste laboratorium muzycznego czasu. Kompozytor tworzył serie wartości rytmicznych ułożonych od najkrócej trwającej do najdłuższej. Takie zestawienia symbolizowały jednoczesny upływ czasu, ale także jego „zatrzymanie”, ponieważ każda następująca wartość zawierała w sobie poprzednią. Zestawione obok siebie pozostawały w asymetrycznej relacji czasowej. Messiaen „rozbijał” serię, tworząc układy symetryczne, np. zestawiając obok siebie pierwszą i ostatnią wartość, drugą i przedostatnią itd., tworząc swoisty układ „wachlarzowy” (Darbyshire, 1988: 46).
} 
Otto, 1993). W obsadzie znajduje się bogaty zestaw instrumentów dętych drewnianych (m.in. flet piccolo i flet en sol), potężna w brzmieniu grupa instrumentów dętych blaszanych z potrójnym puzonem oraz tubą, 10-głosowy chór prowadzony we wzrastającej dynamice, w grupie smyczkowej poczwórne divisi w pierwszych i drugich skrzypcach, potrójne w altówkach i wiolonczelach, oraz instrumenty perkusyjne: trójkąt, podwójne dzwony, gong i tam-tamy ${ }^{19}$. Ta ostatnia grupa wydaje się najbardziej istotna dla spotęgowania wrażenia éblouissement. Messiaen podkreśla tajemniczość brzmienia instrumentów perkusyjnych:

Ces instruments nous offrent la puissance, la poésie et l'irréalité, autant les vibraphones avec leur résonance vibrée que les gongs, les tam-tams et les cloches avec leur halo d'harmoniques, leurs résultantes de fausses fondamentales et autres phénomènes sonores très complexes qui nous rapprochent d'ailleurs de certains bruits énormes et étranges de la nature comme les cascades et les torrents de montagne.

(Messiaen, 1986: 61) $)^{20}$

Najatrakcyjniejszą jakością tego zestawu instrumentarium z punktu widzenia Messiaena jest zjawisko rezonansu. To właśnie halo - aureola dźwiękowa - staje się słyszalnym ekwiwalentem wizualnego symbolu świętości. Tę samą właściwość przypisuje kompozytor falom Martenota, które mogą stworzyć eteryczną poświatę dźwiękową (Messiaen, 1986: 62). Instrument ten w spektaklu Messiaena gra rolę wioli, na której Anioł wygrywa swoją niebiańską muzykę, prowadząc figuracje oparte na modi. W tle brzmi czysty akord $C$-dur, rezonujący w wokalizie chóru, który staje się symbolem obecności Boga, podobnie jak w poprzednich obrazach opery, gdzie wypowiedzi Chrystusa w muzycznym opracowaniu były prezentowane przez zespół wokalny. Nie bez znaczenia pozostaje również wybór tonacji: C-dur kojarzy się z prostotą, naturalnością, klarownością, a także majestatem, jak np. w Symfonii Jowiszowej, KV 551 Wolfganga Amadeusza Mozarta - ulubionego kompozytora Messiaena.

\footnotetext{
19 Tam-tam to instrument o nieokreślonej wysokości. Jego charakterystyczną cechą jest rezonans, a więc właściwość zatrzymania w swoim brzmieniu dźwięków orkiestry. Aby kolejne współbrzmienia orkiestry nie nakładały się na siebie, tam-tam musi być tłumiony. Działa podobnie do prawego pedału fortepianu, powodując przedłużenie dźwięków dobiegających z zewnątrz oraz ich nawarstwianie się (Drobner, 1997: 225).

20 „Instrumenty te dają nam moc, poezję i nadprzyrodzoną jakość: wibrafony z ich drżącym rezonansem, gongi, tam-tamy, dzwony z ich halo alikwotowym i brakującą częstotliwością podstawową, i inne bardzo skomplikowane zjawiska dźwiękowe, które przybliżają nas do potężnych i dziwnych odgłosów natury, jak wodospad czy górskie strumienie”.
} 
$\mathrm{Na}$ tle rezonującego wibrafonu - w dźwiękowej aureoli - Anioł kieruje pierwsze słowa do Franciszka: „Ach! Bóg olśniewa [oślepia] nas nadmiarem Prawdy”. Westchnienie zostaje zilustrowane skokiem oktawowym - symboliczną figurą w porządku wertykalnym, po czym kolejne słowa rozbrzmiewają w oparciu o konstrukcję trytonową - kwarta zwiększona, idealna połowa oktawy to ulubiony interwał Messiaena. W jego języku muzycznym trytonowe zakończenie frazy to rodzaj najczęściej występującej kadencji (Kaczyński, 1984: 34). Fragment ten wykorzystuje najbardziej podstawowe według kompozytora modi - 2. i 3. w trzeciej transpozycji. „Mode 2. - jak pisał kompozytor - rozwija się wokół fioletów, błękitu i fioletowopurpurowego" (Messiaen, 1986: 45). Kolor fioletowy jest ulubioną barwą kompozytora, ponieważ stanowi połączenie dwóch skrajności: gorącej czerwieni i chłodnego błękitu (Messiaen, 1986: 46). Mode ta odwołuje się również do wyglądu Anioła z przedstawienia Fra Angelico. Posłaniec boski ma na skrzydłach pasma w tych odcieniach kolorystycznych. Messiaenowską predylekcję do wskazanych barw wykorzystał w swojej realizacji scenicznej z 2009 roku Pierre Audi, wyposażając Anioła w dwa pale: koloru czerwonego i niebieskiego, symbolizujące niebiański instrument.

\section{Słowo w dźwięku}

Kompozytor nie tylko odzwierciedla w muzyce barwne fenomeny, ale także konkretne znaczenia tekstu. Obok melodyki posługuje się w tym celu również tworzywem rytmicznym. Środkowej sylabie w wyrazie vérité kompozytor przypisał tzw. wartość dodaną, która literalnie oddaje „nadmiar Prawdy”. Symbolicznie i tradycyjnie traktuje Messiaen również rejestr. Tam, gdzie w tekście mowa o Bogu, fraza kończy się na wysokich dźwiękach. Szczególnie wyraźne jest to w przypadku następującego zdania: „Mówisz do Boga muzyką: on odpowie ci muzyką”. Ma ono budowę symetryczną - Messiaen zachowuje tę lustrzaność w budowie linii melodycznej. Pierwsza część umuzyczniona jest frazą opadającą i kończy się na $g^{l}$ na tle akordu Es-dur, zaś druga ma kierunek wznoszący oraz jest zwieńczona $g^{2}$, rozbrzmiewającym w otoczeniu klasteru. Kolejne wersy: „Poznaj radość błogosławionych poprzez słodycz kolorów i melodii” prowadzą poprzez rozłożony trójdźwięk zmniejszony aż do najwyższego dźwięku w ambitusie Anioła - $a s^{2}$ utrzymanego w dynamice ff na słowie couleur i ponowne zwiększenie wolumenu od $f$ do $f f$ na słowie mélodie, które ma przypisany motyw złożony z dźwięków $e-e s-d e s-c-b$. Środkowe dźwięki tej krótkiej myśli muzycznej (es-des-c) pojawiają się pod koniec pierwszej frazy 
w grze Anioła na wioli. Messiaen - podwójną kulminacją, najpierw prowadzącą do „koloru”, potem do „melodii” - podkreśla istotność synestezyjnego postrzegania fenomenów zmysłowych. Tu znajduje się jego muzyczna definicja éblouissement.

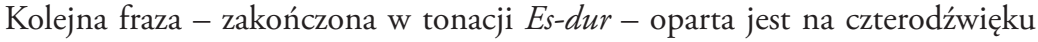
zmniejszonym. Budowanie linii melodycznej z dźwięków tego współbrzmienia nie jest przypadkowe. Czterodźwięk zmniejszony jest jedną z zamkniętych formuł harmonicznych. Jego składniki powtarzać można przechodząc przez wszystkie oktawy: $e-g-b-c i s(d e s)$. Nie mają również początku ani końca. W tym sensie stają się figurą wiedzy tajemnej, wyrażając „sekrety chwały” (les sécrets de la gloire.). Z kolei akord Es-dur, brzmiący konsonansowo i majestatycznie, może oznaczać nadzieję odsłonięcia Prawdy. „Usłysz muzykę niewidzialnego”, powiada następnie Anioł. Jego wypowiedź kończy mało „substancjalny” akord g-moll, postawiony na tercji i dobarwiony dźwiękiem as, który symbolicznie oddaje ulotność niebiańskiej muzyki.

Aniołowi kontrapunktuje ptasi śpiew. Po pierwszym zwrocie do św. Franciszka, opartym na trytonie, następuje ponad 30 taktów ptasiego intermezza. Stanowią one odzwierciedlenie synchronii autonomicznych ptasich głosów, które, choć niezestrojone rytmicznie w naturze, tworzą według kompozytora doskonałą harmonię (Messiaen, 1986: 87). Grupa instrumentów dętych drewnianych - przede wszystkim flet piccolo i flety - oraz smyczki imitują równocześnie śpiew ptaków z Nowej Kaledonii oraz Japonii, m.in. zosteropsa, japońską hòake, gajówkę ogrodową, kapturkę (inaczej pokrzewkę czarnołbista) oraz gerygone. Skrzydlaci bracia reagują bardzo żywiołowo na obecność Anioła. Całe stworzenie w lesie, w którym modli się św. Franciszek, drży od słów Boskiego posłańca. Świat reaguje na obecność sacrum i oczekuje Zbawiciela, co nasuwa skojarzenie ze słynnym fragmentem z pism św. Pawła: „Stworzenie bowiem zostało poddane marności - nie z własnej chęci, ale ze względu na Tego, który je poddał - w nadziei, że również i ono zostanie wyzwolone z niewoli zepsucia, by uczestniczyć w wolności i chwale dzieci Bożych. Wiemy przecież, że całe stworzenie aż dotąd jęczy i wzdycha w bólach rodzenia” ( $\mathrm{Rz} 8,20-22)$.

Éblouissement wyrażone zostaje zatem na kilku poziomach dzieła scenicznego. W tworzywie wizualnym niebagatelną rolę odgrywa operowanie światłem scenicznym, a także kolorowy kostium Anioła. W muzyce barwy tworzą: modi, dobór instrumentów, symbolicznie traktowane akordy - A-dur (nr 48), które pojawia się tuż po wzniesionej przez Franciszka modlitwie; Es-dur - które często wieńczy wersety wypowiadane przez Anioła; oraz $C$-dur, będące tłem dla anielskiej improwizacji na wioli. Warto zwrócić uwagę, że podstawowe dźwięki tych współbrzmień ułożone od a do es zamykają się w trytonie i tworzą akord zmniejszony. W tworzywie melodyczno-rytmicznym obserwujemy permutacje symetryczne na skali 
dwunastotonowej, które symbolizują wyjście z ziemskiego czasu. Wielkie znaczenie ma również walor sopranowego głosu Anioła, jaśniejący barwą na tle pozostałych, wyłącznie męskich głosów. Partia ta staje się również w układzie wertykalnym znakiem sacrum i symbolem muzycznego pośrednictwa między człowiekiem a Bogiem. Mediacja ta w samym dziele Messiaena odbywa się na kilku poziomach: w jego muzycznej teologii, idiomie kompozytorskim oraz naocznie w postaci anielskiej, jaką wprowadza do swojej jedynej opery. Obecność Anioła jest zawsze zwiastunem wewnętrznej przemiany bohaterów, począwszy od sceny, w której św. Franciszek pokonuje strach przed chorobą Trędowatego, aż po mistyczne doświadczenie Asyżanina, wywołane grą boskiego posłańca.

Wydaje się, że Messiaenowi nie chodziło tylko o sugestywne przedstawienie momentu przemienienia św. Franciszka, lecz przede wszystkim - o jednoczesną transfigurację słuchacza poprzez bezpośrednią percepcję polisensoryczną ${ }^{21}$. Estetycznym środkiem - swoistym passaggio - który ma prowadzić do transfiguracji, było éblouissement, wrażenie towarzyszące doświadczeniu mistycznemu. W operze Messiaena jest ono efektem wielopoziomowego współdziałania kilku mediów, przeplatających się wzajemnie: muzyki, słowa, obrazu, tańca, ale także fuzji elementów z różnych kultur. Posługując się narzędziami intermedialności skonstruowanymi przez Wernera Wolfa, można by odnaleźć w utworze następujące rodzaje relacji: 1) libretto-literatura - transpozycja intermedialna (proces adaptacji); 2) muzykasłowo - kombinacja intermedialna; 3) dźwięk-obraz - transmedialność w formie kolorystyki oraz odniesienie implicytne jako imitacja sztuk plastycznych poprzez uprzestrzennienie muzyki (synestetyczne tworzenie kombinacji kolorystycznych); 4) scenografia-obraz - transpozycja konkretnych dzieł malarskich na kostium i postawę głównego bohatera (Wolf, 2002: 28). To wzajemne przeplatanie się implicytnie zawiera się w założeniach samego gatunku opery, jednak w przypadku Messiaena być może ważniejszą kwestią jest intermedialność samego tworzywa dźwiękowego. To właśnie muzyka wyznacza czas (poprzez nacechowane symbolicznie figury rytmiczne, np. rytmy nieodwracalne jako znak wieczności) oraz przestrzeń (poprzez

21 Motyw przemienienia, zarówno tego na górze Tabor, jak i przyszłego przebóstwienia człowieka, jest jednym z ulubionych wątków wiary chrześcijańskiej, a może nawet pewną obsesją artystyczną Messiaena. Kompozytor poświęca mu w całości swoje wielkie oratorium La Transfiguration de Notre Jésus-Christ, które poprzedziło skomponowanie opery (Maas, 2007: 83). 
naddany element kolorystyczny) doświadczenia éblouissement. Muzyka, otwierając się na nieswoiste dla siebie jakości, traci swoją substancjalność, jednak potęguje swoją energię znaczeniową. Transgresyjny charakter opery, dynamiczna mozaikowość medialna, miała być dla widza oszałamiająca, zaś obecne w niej miejsca graniczne stają się ,pustymi” przestrzeniami, przez które prześwieca, wyjawia się coś nieznanego, a co jest źródłem oślepienia. Plurimedialność - powołana do życia w akcie wystawienia scenicznego - nie tylko staje się samym narzędziem éblouissement, ale, poprzez zwielokrotnienie mediów i jednoczesne ich osłabienie, wpływa na bezpośredniość przekazu i zmniejszenie dystansu między widzem a dziełem. Na tę cechę intermedialności zwrócił uwagę Éric Méchoulan, określając jej oddziaływanie jako bezpośrednie, „natychmiastowe” (l'immédiat) (Méchoulan, 2003: 13, 15, 22), wkraczające w obszar egzystencji, mniej zaś skoncentrowane na eksponowaniu - jak dopowiada Andrzej Hejmej - „materialności mediów, strategii i mechanizmów artystycznej mediatyzacji” (Hejmej, 2013: 115).

Podobnie o swoim języku muzycznym pisał sam kompozytor. Wyjaśniając pewne symbole ukryte w tkance dźwiękowej, mianowicie ograniczoną ilość transpozycji skal i rytmy nieodwracalne jako tajemne i zamknięte formuły, podkreślał jednocześnie, że ich znajomość nie jest odbiorcy potrzebna:

(...) w czasie koncertu [słuchacza] nie będzie interesować zagadnienie nietranspozycyjności i nieodwracalności (...). Być oczarowanym - to będzie jego pragnienie. I tak właśnie się stanie: słuchacz ulegnie mimo woli dziwnemu czarowi niemożliwości, wrażeniu wszechobecności tonalnej w nietranspozycyjności - pewnej jedności ruchu w nieodwracalności (początek i koniec stają się jednym - identyfikują się) - wszystkiemu, co stopniowo prowadzi go do tego rodzaju „tęczy teologicznej” - poszukiwanego języka muzycznego, któremu pragniemy nadać teoretyczną podbudowę ${ }^{22}$.

(Messiaen, 1973: 145)

Saint François d'Assise niesie w sobie tak wiele bogactw znaczeniowych, ukrytych na granicy słowa, muzyki i obrazu, że każda próba odczytania wydaje się niepełna, wręcz uboga i bezsilna. Niniejsze rozpoznania ograniczają się do zasygnalizowania potencjału intermedialności jako narzędzia badania samej „instrukcji” kompozytora zawartej w libretcie, uwagach i zapisie nutowym partytury. Claus Clüver - nie bez racji - zaznacza potrzebę badania fenomenu opery w jej żywiole scenicznym jako efektu performatywnej fuzji mediów, pracy kompozytora, reżysera, dyrygenta, scenografa, choreografa itd. (Clüver, 2007: 24-25). Takie ujęcie dzieła Messia-

22 Cytat przytaczam w przekładzie Józefa Świdra. 
ena niewątpliwie jest zadaniem koniecznym, jednak przekraczającym ramy tego krótkiego studium. Najważniejsze - z obranego punktu widzenia - wydaje się podkreślenie duchowego i teologicznego wymiaru, jaki w zakrojonym projekcie Messiaena - dzięki intermedialności gatunkowej oraz tej ukrytej w idiomie kompozytorskim - zyskuje opera. Muzyka i śpiew na powrót stają się łącznikiem między ziemią a zaświatami, podobnie jak w Orfeuszu Claudia Monteverdiego, zaś inkrustowana barwnymi konstelacjami melodyka, niesiona przez głos i instrumenty, zamienia się w audialną ikonę, która stanowi wyraz jednoczesnej nadziei oraz tęsknoty za tym, co Niewyrażalne.

\section{Bibliografia}

Antoine, Louis. Lire François d'Assise. Paris: Éditions franciscaines, 1967.

Benson, Alan. Olivier Messiaen: The Music of Faith (film dokumentalny). London Weekend Television, 1986.

Biblia Tysiaclecia. Red. ks. Kazimierz Dynarski SAC, Maria Przybył. Poznań: Wydawnictwo Pallottinum, 2012.

Bruhn, Siglind. Messiaen's Interpretations of Holiness and Trinity. Echoes of Medieval Theology in the Oratorio, Organ Meditations and Opera. Hillsdale: Pendragon Press, 2008.

Clüver, Claus. „Intermediality and Interart Studies”. Borders. Contemporary Positions in Intermediality. Eds. Jens Arvidson, Mikael Askander, Jørgen Bruhn, Heidrun Führer. Lund: Intermedia Studies Press, 2007. 19-37.

Darbyshire, Ian. „Messiaen and the Representation of the Theological Illusion of Time”. Messiaen's Language of Mystical Love. Ed. Siglind Bruhn. New York-London: Garland Publishing, 1998. 33-51.

Dingle, Christopher Philip. „Frescoes and Legends: The sources and Background of Saint François d'Assise". Olivier Messiaen: Music, Art and Literature. Eds. Christopher Philip Dingle, Nigel Simeone. Burlington: Ashgate Publishing Limited, 2007. 302-304.

Drobner, Mieczysław. Instrumentoznawstwo i akustyka. Kraków: Polskie Wydawnictwo Muzyczne, 1997.

Hejmej, Andrzej. Komparatystyka. Studia literackie - studia kulturowe. Kraków: Universitas, 2013.

Huston Bell, Carla. Olivier Messiaen. Boston: Twayne Publishers, 1984.

Kaczyński, Tadeusz. Messiaen. Kraków: Polskie Wydawnictwo Muzyczne, 1984. 
Keym, Stefan. Farbe und Zeit: Untersuchungen zur musiktheatralen Struktur und Semantik von Olivier Messiaens Saint François d'Assise. Hildesheim-Zürich-New York: Olms, 2002.

Maas van, Sander. „Forms of love: Messiaen's aesthetics of éblouissement”. Messiaen Studies. Ed. Robert Sholl. Cambridge: Cambridge University Press, 2007. 78-100.

----. The Reinvention of Religious Music: Olivier Messiaen's Breakthrough Toward the Beyond. New York: Fordham University Press, 2009.

Méchoulan, Éric. „Intermédialités: le temps des illusions perdues”. Intermédialités 1 (2003): 9-27.

Messiaen, Olivier. Conférence de Bruxelles, Paris: Alphonse Leduc, 1960.

----. Lecture at Notre-Dame. Trans. Timothy J. Tikker. Paris: Alphonse Leduc, 2001.

----. „Première note de l'auteur”. Couleurs de la cité céleste. Paris: Alphonse Leduc, 1963.

----. „Saint François d'Assise. Scènes franciscaines en trois actes et huit tableaux” (libretto). Commentaire littéraire et musical de Harry Halbreich (1992), complété et augmenté par Hélène Cao pour cette edition (2004). L'Avant-Scène Opéra. „Saint François d'Assise" 223 (2004): 11-49.

----. Saint François d'Assise: scènes franciscaines: opéra en 3 actes et 8 tableaux/poème et musique d'Olivier Messiaen. T. 1-5. Paris: Alphonse Leduc, 1988-1992.

----. „Technika mojego języka muzycznego”. Przeł. Józef Świder. Res Facta 3 (1973): 135-242.

----. Traité de rhythme, de couleur, et d'ornithologie. T. 1. Paris: Alphonse Leduc, 1994.

Messiaen, Olivier, Claude Samuel. Musique et couleur: nouveaux entretiens avec Claude Samuel. Paris: Belfond, 1986.

Otto, Rudolf. Świętość. Elementy racjonalne i irracjonalne w pojęciu bóstwa. Przeł. Bogdan Kupis. Wrocław: Thesaurus Press, 1993.

Pople, Anthony. „Messiaen's Musical Language: an Introduction”. The Messiaen Companion. Ed. Peter Hill. London-Boston: Faber and Faber, 1995.

Shenton, Andrew. „Speaking with the Tongues of Men and Angels: Messiaen's langage communicable". Messiaen's Language of Mystical Love. Ed. Siglind Bruhn. New York-London: Garland Publishing, 1998. 225-246.

Św. Tomasz z Akwinu. Summa teologiczna. Prawo (1-2. 90-105). Przeł., w objaśnienia i skorowidze zaopatrzył Pius Bełch OP. London: Veritas, 1985.

Wolf, Werner. „Intermediality Revisited. Reflections on Word and Music Relations in the Context of a General Typology of Intermediality". Word and Music Studies. Essays in Honor of Steven Paul Scher and on Cultural Identity and the Musical Stage. Eds. Suzanne M. Lodato, Suzanne Aspden, Walter Bernhart. Amsterdam-New York: Editions Rodopi, 2002. 13-34.

Zawadzki, Andrzej. Obraz iślad. Kraków: Wydawnictwo Uniwersytetu Jagiellońskiego, 2014 . 


\title{
Theology on the Crossroads of a Word, Music and Image. The Case of Olivier Messiaen's Opera Saint-François d'Assise
}

\begin{abstract}
Summary
The article examines intermediality as a means to express the theological-like experience of éblouissement (dazzlement), pertinent in Messiaen's Saint François d'Assise, which has aesthetical roots, but guides a listener to a mystical breakthrough toward the "beyond". Intermediality functions as an intrinsic quality of the genre of the opera, but also has a deep impact on Messiaen's musical language, which is strongly inspired by word (in rhythm) and image (the coloured properties of musical scales, originally named modes). The opera also incorporates elements of other cultures and ways of thinking, for example Indian rhythms exposed as religious symbols of time and eternity are enriched by Thomas Aquinas's philosophical background and the theologian's thinking about artistic means to convey God's message. The richness of the intertwined media - while reciprocally weakened by their multiplicity - should express the dazzlement experienced by Saint Francis on stage. Eventually it seems that Messiaen's aim was imprinting the same feeling in the audience.
\end{abstract}

Keywords: comparative literature, intermediality, word and music studies, theology, opera, Olivier Messiaen, Francis of Assisi

Słowa kluczowe: literatura porównawcza, intermedialność, związki muzyki z literaturą, teologia, opera, Olivier Messiaen, św. Franciszek z Asyżu 